\title{
The targeted LHRH analog AEZS-108 alters expression of genes related to angiogenesis and development of metastasis in uveal melanoma
}

\author{
Klara Fodor ${ }^{1}$, Nikoletta Dobos ${ }^{1}$, Andrew Schally ${ }^{2,3}$, Zita Steiber ${ }^{4}$, Gabor Olah ${ }^{1}$, Eva \\ Sipos $^{1}$, Lorant Szekvolgyi ${ }^{5}$ and Gabor Halmos ${ }^{1,2}$ \\ ${ }^{1}$ University of Debrecen, Department of Biopharmacy, Debrecen, Hungary \\ ${ }^{2}$ Veterans Affairs Medical Center, Endocrine, Polypeptide and Cancer Insitute, Miami, FL, USA \\ ${ }^{3}$ University of Miami, Miller School of Medicine, Department of Pathology and Department of Medicine, Divisions of Oncology \\ and Endocrinology, Sylvester Comprehensive Center, Miami, FL, USA \\ ${ }^{4}$ University of Debrecen, Department of Ophthalmology, Debrecen, Hungary \\ ${ }^{5}$ University of Debrecen, Faculty of Medicine, Department of Biochemistry and Molecular Biology, MTA-DE Momentum, \\ Genome Architecture and Recombination Research Group, Debrecen, Hungary \\ Correspondence to: Gabor Halmos, email: halmos.gabor@pharm.unideb.hu \\ Keywords: uveal melanoma; luteinizing hormone-releasing hormone (LHRH) receptor; angiogenesis; MASPIN/SERPINB5; AEZS-108 \\ (AN-152/Zoptarelin Doxorubicin Acetate) \\ Received: December 05, 2019 Accepted: December 29, $2019 \quad$ Published: January 14, 2020
}

Copyright: Fodor et al. This is an open-access article distributed under the terms of the Creative Commons Attribution License 3.0 (CC BY 3.0), which permits unrestricted use, distribution, and reproduction in any medium, provided the original author and source are credited.

\section{ABSTRACT}

Uveal melanoma (UM) is the most common malignant tumor of the eye. Recently, we have established that $46 \%$ of UM specimens express LHRH receptors. This finding supports the idea of a LHRH receptor-targeted therapy of UM patients. Cytotoxic analog of LHRH, AEZS-108 exhibits effective anti-cancer activity in LHRH-receptor positive cancers. AEZS-108 is a hybrid molecule, composed of a synthetic peptide carrier and the cytotoxic doxorubicin (DOX). In the present study, we investigated AEZS-108 induced cytotoxicity and the altered mRNA expression profile of regulatory factors related to angiogenesis and metastasis in LHRH receptor positive OCM3 cells. Our results show that AEZS-108 upregulates the expression of MASPIN/SERPINB5 tumor suppressor gene, which is downregulated in normal uvea and UM specimens independently from the LHRH receptor-ligand interaction. AEZS-108 also substantially downregulates hypoxia-inducible factor 1 alpha (HIF1A) expression. In order to investigate the mechanism of the induction of MASPIN by AEZS-108, OCM 3 cells were treated with free DOX, D-Lys ${ }^{6}$ LHRH analog, or AEZS-108. qRT- PCR analysis revealed in OCM3 cells that AEZS-108 is a more potent inducer of MASPIN than free DOX. In conclusion, we show for the first time that AEZS-108 has a major impact in the regulation of angiogenesis thus plays a potential role in tumor suppression. Taken together, our results support the development of novel therapeutic strategies for UM focusing on LHRH receptors.

\section{INTRODUCTION}

Although uveal melanoma (UM) is a rare disease, it is the most prevalent lethal ophthalmological tumor [1, 2]. Approximately $50 \%$ of the patients already manifests distant metastases, mostly in the liver at the time of the diagnosis [2]. In spite of the currently available systemic therapies, $90 \%$ of the patients with metastasis die within
1 year of the diagnosis of UM $[3,4]$. Chemotherapy or partial hepatectomy only rarely prolongs the survival, emphasizing the necessity of developing more effective therapies [5].

The discovery of specific receptors for peptide hormones on cancer cells has led to the development of cytotoxic or radiolabeled hormone analogs that are appropriate for tumor localization and targeted therapy. 
Numerous preclinical studies have demonstrated the efficacy of chemotherapy based on cytotoxic peptide conjugates targeted to receptors on different tumors [6-10]. Clinical trials confirmed that targeted cytotoxic LHRH analog can improve the effectiveness of treatment and reduce general side effects [11-13].

Luteinizing Hormone-Releasing Hormone (LHRH) and its receptor (LHRH-R) are not limited to the hypothalamic-pituitary axis [14-18]. In the periphery, the LHRH system regulates gonadal functions and appears to serve as a growth factor of benign prostate hyperplasia $[10,19-21]$ and even in various cancers, including breast, lung, ovary, endometrial, urinary, colon, pancreas and prostate cancer [22-31].

In our previous study, we have revealed that more than $40 \%$ of human uveal melanomas express LHRH receptor type I [1]. AEZS-108 (formerly known as AN-152 / INN: Zoptarelin Doxorubicin Acetate) is a targeted cytotoxic LHRH-analog consisting of doxorubicin conjugated to D-Lys ${ }^{6}$ LHRH. AEZS-108 guides the chemotherapeutic agent specifically to those tumors that express LHRH-receptors, which could result in targeted cytotoxicity and less damage to healthy tissues $[9,11,13,30,32]$. AEZS-108 has been utilized in phase III clinical trials in advanced, recurrent or metastatic endometrial cancer, in phase I-II in castration resistant prostate cancer and ovarian cancer [9, 11, 13, 32]. Moreover, AEZS-108 was found to be able to inhibit the growth of doxorubicin resistant cells $[31,33]$.

In the present study our aim was to demonstrate the antitumor effects of AEZS-108 in a human uveal melanoma cell line. As we reported it previously OCM3 UM cell line express the receptor of LHRH localized on the cell membrane and in the cytoplasm, rendering them susceptible to AEZS-108 uptake $[33,34]$. The detection of LHRH receptor in OCM3 cells has led to use AEZS-108 for targeted therapy of the tumor. Our results shows that AEZS-108, as well as doxorubicin significantly inhibited the proliferation of OCM3 human uveal melanoma cells. Angiogenesis has a pivotal role in the development of UM because lymphatic vessels are not present in the eye to promote distant metastasis $[35,36]$. This special characteristics of UM also led us to investigate the effect of AEZS-108 on the expression of the genes involved in angiogenesis and metastasis in an in vitro model of UM. The qRT-PCR array results showed that AEZS-108 altered the expression of MASPIN, HIF $1 A$ and its target genes. Furthermore, qRT-PCR analysis revealed that AEZS-108 is a more potent inducer of MASPIN tumor suppressor than free DOX in OCM3 cells. MASPIN has been shown to be downregulated in normal uvea and UM tumor specimens.

Western blot analysis confirmed that the greatest changes of mRNA expression are at protein levels as well. To conclude, we report here, that OCM3 UM cell line expresses the LHRH receptor and LHRH rendering them susceptible to AEZS-108 uptake. AEZS-108 treatment resulted in changes in the expression of genes involved in the extracellular matrix (ECM) remodelling and angiogenesis. Our findings support the novel notion that AEZS-108 might be suitable as a potential drug candidate in targeted therapy of uveal melanoma.

\section{RESULTS}

\section{OCM3 human uveal melanoma cell line expresses the human LHRH receptor type I}

Expression and cellular distribution of the full length LHRH receptor type I in OCM3 cells was demonstrated by RT-PCR and by immunocytochemistry (Figure 1). The expected 319 bp PCR product, amplified with gene specific primers, was detected successfully in OCM3 cell line. Our result was confirmed also at protein levels by immunocytochemistry. We found that full length LHRH receptors are present in the cell membrane and therefore in the cytoplasm, so they might play a role in the facilitation of the selective uptake of AEZS-108 in OCM3 cells.

\section{AEZS-108 and doxorubicin induces comparable cytotoxicity in $\mathrm{OCM} 3$ cells}

In order to investigate whether AEZS-108 inhibits cell proliferation and its extent, OCM3 cells were treated either with $5 \mu \mathrm{M}$ AEZS-108 or equal amount of doxorubicin. MTS assay was performed after 24 and 48 hours of treatment. AEZS-108 and doxorubicin have been shown to reduce cell proliferation by $36.3 \%(p<0.001)$ and $62.9 \%(p<0.001)$ respectively after 24 hours, and by $84.7 \%(p<0.001)$ and $89.7 \%(p<0.001)$ respectively after 48 hours, (Figure 2).

\section{AEZS-108 alters the expression of angiogenesis and metastatis regulatory factors in OCM3 cells}

We have investigated the role of AEZS-108 in the expression of 94 key regulatory genes involved in angiogenesis and development of metastasis in OCM3 cells. MASPIN (SERPINB5), SERPINE1 (PAI-1), $C X C R 4, V E G F A$ and $M A P K 7$ genes have been found to be significantly upregulated, while $A N G P T 1, H I F 1 A$, ANGPTL3, ETS1, VEGFB, CEACAM and SURVIVIN genes were significantly downregulated $(p<0.05)$ as compared to control (untreated) cells. The tumor suppressor gene MASPIN (SERPINB5) showed the highest overexpression (203.19× upregulation), while the most significantly downregulated gene was $H I F 1 A(8.67 \times$ downregulation) (Tables 1 and 2).

\section{AEZS-108 provokes higher expression of MASPIN than free DOX}

The expression of MASPIN tumor suppressor gene was further investigated by qRT-PCR. OCM3 cells were 


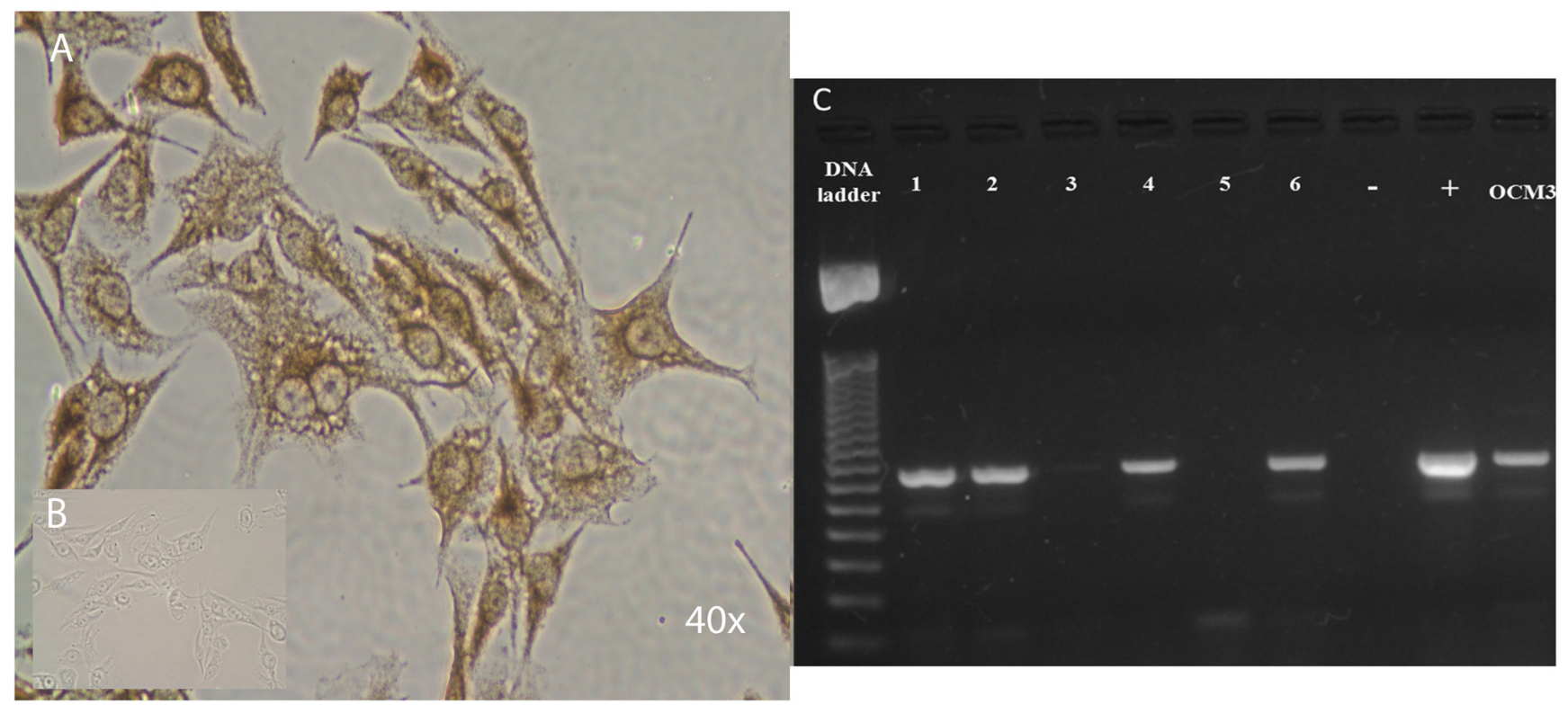

Figure 1: (A) Strong positivity of the full length LHRH receptor as detected by specific antibody in the nucleus, in the cytoplasm and in the membrane by DAB-immunoperoxidase staining. (B) Insert is a negative control for the staining-specificity. Original magnifications of images in immuncitochemistry: $40 \times$. (C) Expression of LHRH receptor type I in OCM3 human uveal melanoma cells. The expected PCR products amplified with gene specific primers with 319 bp were detected successfully in OCM3 cell line. DNA ladder: 50 bp ladder (Fermentas), +: positive control (human pituitary); -: no template control, No. 1-6: representative human uveal melanoma tissues.

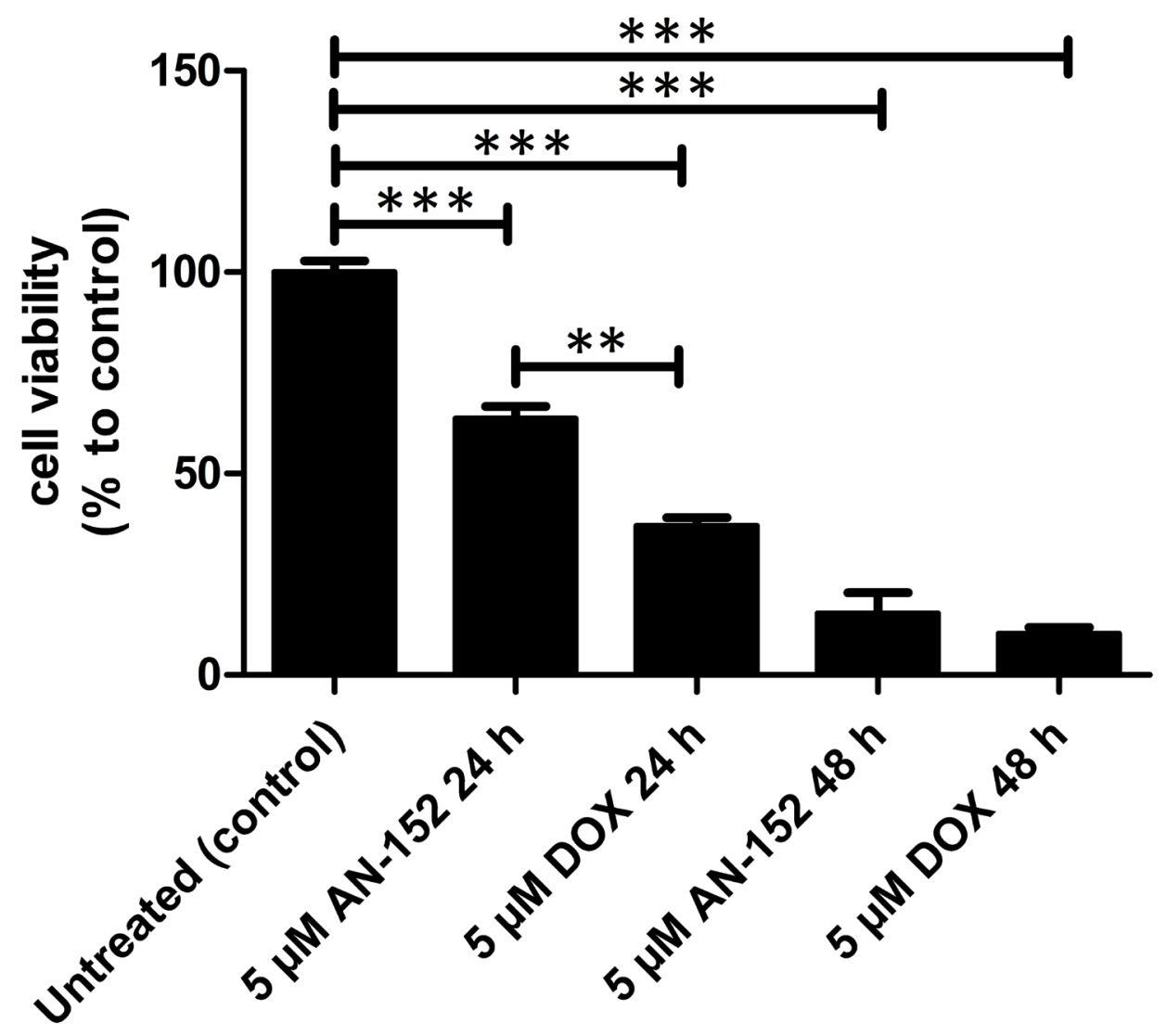

Figure 2: The cytotoxicity of AEZS-108 and DOX in OCM3 cells. The effect of treatment with $5 \mu$ M AEZS-108 and $5 \mu$ M DOX for 24 and 48 hours on cell viability of OCM3 cells was measured by MTS assay in complete medium. Statistical analysis was performed by one-way ANOVA $\left({ }^{* *}\right.$ : highly significant, $p<0.01$; $^{* * *}$ : extremely significant, $\left.p<0.005\right)$. 
Table 1: In vitro results of significantly upregulated genes following $5 \mu \mathrm{M}$ AEZS-108 treatment in OCM3 cells

\begin{tabular}{llc}
\hline Symbol of gene & Upregulation (treated/control) & $\boldsymbol{p}$ value \\
\hline MASPIN (SERPINB5) & +203.19 & 0.0021 \\
SERPINE1(PAII) & +52.59 & 0.0109 \\
CXCR4 & +15.45 & 0.0052 \\
VEGFA & +3.48 & 0.0005 \\
MAPK7 & +2.27 & 0.0354 \\
\hline
\end{tabular}

Results were normalized by the Global Pattern Recognition algorithm (Bar Harbor BioTechnology Inc.'s, USA), and quantified by $\Delta \Delta \mathrm{Ct}$ method. Differences between the expression of genes between groups were tested for statistical significance level using Student's $t$-test. (significant: $p<0.05$ ).

Table 2: In vitro results of significantly downregulated genes following treatment with $5 \mu \mathrm{M}$ AEZS108 in OCM3 cells

\begin{tabular}{lcc}
\hline Symbol of gene & Downregulation (treated/control) & $\boldsymbol{p}$ value \\
\hline ANGPT1 & -32.00 & 0.0220 \\
HIF1A & -8.67 & 0.0187 \\
ANGPTL3 & -6.57 & 0.0433 \\
ETS1 & -5.66 & 0.0036 \\
VEGFB & -5.10 & 0.0230 \\
CEACAM1 & -4.14 & 0.0082 \\
SURVIVIN & -3.91 & 0.0007 \\
\hline
\end{tabular}

Results were normalized by the Global Pattern Recognition algorithm (Bar Harbor BioTechnology Inc.'s, USA), and quantified by $\Delta \Delta \mathrm{Ct}$ method. Differences between the expression of genes between groups were tested for statistical significance level using Student's $t$-test. (significant: $p<0.05$ ).

treated with AEZS-108, D-Lys ${ }^{6}$ LHRH analog or free DOX. Our results clearly showed that D-Lys ${ }^{6}$ LHRHtreated cells do not express MASPIN, while free DOX and AEZS-108 induces MASPIN expression. However, equal dose of AEZS-108 and DOX show significantly different effect on MASPIN expression, namely, that AEZS108 treatment results in significantly higher MASPIN expression than free DOX treatment (Figure 3).

\section{The tumor suppressor MASPIN is not expressed in uveal melanoma or in normal uvea tissue specimens}

The mRNA expression of MASPIN has been investigated in 3 healthy and 18 human uveal melanoma tissue specimens by real time PCR. Our results did not show mRNA expression of MASPIN in healthy or in uveal melanoma tissues (data not shown).

\section{AEZS-108 alters MASPIN, HIF1A, VEGFA and VEGFB protein expression in OCM3 cells}

Protein levels of MASPIN, HIF1A, VEGFA and VEGFB have also been examined. SDS PAGE Western blot analysis confirmed the qRT-PCR results, namely, that MASPIN production in untreated OCM3 cells is very low, however, treatment with AEZS-108 or free DOX slightly increases the expression of MASPIN tumor suppressor (Figure 4). As seen at mRNA and protein levels, AEZS108 is a more potent inducer of MASPIN than free DOX. Furthermore, in order to unravel whether AEZS-108 or free DOX has an effect on angiogenesis, HIF1A and its target proteins, VEGFA and VEGFB angiogenesis related proteins were also investigated. Our data showed that treatment with AEZS-108 and DOX significantly decreased HIF1A, VEGFA and VEGFB expression (Figure 4).

\section{DISCUSSION}

Although uveal melanoma is very rare, it is the most common primary intraocular malignant cancer and the second most common primary malignant melanoma in humans [4]. Death usually occurs within a year of the onset of systemic symptoms [3, 4]. The liver is a virtual "sentinel lymph node" for uveal melanoma since unfortunately it is involved in $95 \%$ of patients with metastasis [4]. The absence of effective therapy for 
metastatic disease offers now a chessboard for targeted therapy, creating new opportunities to develop novel treatment options [36-40].

It has been shown that the growth of various cancer cell lines, e. g. cutaneous melanoma xenografted into nude mice can be inhibited by analogs of targeted cytotoxic luteinizing-hormone-releasing hormone (LHRH) [41]. Interestingly, our previous results showed that $46 \%$ of specimens of uveal melanoma tissues express LHRH receptor type I [1]. Previous studies have demonstrated that AEZS-108 strongly inhibits the growth of experimental human prostatic, mammary, ovarian and urinary bladder cancers as well as melanomas expressing LHRH receptors [6, 12, 27, 30, 32, 33, 41, 42]. Previous in vivo investigations have demonstrated that AEZS-108 has a prominent antitumor activity and less toxicity than unconjugated DOX in various cancer types [7-9, 11-13, 43]. Upon detection of LHRH receptors in specimens of human uveal melanoma, we have investigated whether AEZS-108, which is appropriate for targeted therapy of various tumors, could serve as a novel therapy in UM.

Our aim was to further elucidate the antitumor effects of AEZS-108 in human UM. As a relevant in vitro model of UM, OCM3 cell line was selected in order to investigate the antitumor-effect of AEZS-108 compared to its unconjugated cytotoxic consituent, doxorubicin. First, we examined the expression of LHRH receptors in OCM3 cells by qRT-PCR and by immunocytochemistry. To demonstrate if AEZS-108 induces cytotoxicity, OCM3 cells were treated with $5 \mu \mathrm{M}$ AEZS-108 or equal amount of doxorubicin and then MTS-assay was performed. Our result show that AEZS-108 reduces cell viability by $36.3 \%$ after 24 hours $(p<0.001)$ and by $84.7 \%$ after 48 hours $(p$ $<0.001)$. In contrast, free DOX led to $62.9 \%(p<0.001)$ and $89.7 \%(p<0.001)$ cell death after 24 and 48 hours, respectively. These results might be explained by the fact, established previously, that some cytotoxic ligand analogs containing DOX show ten times lower antiproliferative activity in vitro than doxorubicin. However, in vivo experiments are in accord with the in vitro results and demonstrate that cytotoxic ligand analogs present high antitumor activity, greater efficacy and less toxicity than doxorubicin [7-9, 32].

Since lymphatic vessels are absent in the eye, angiogenesis plays a pivotal role in the development of $\mathrm{UM}$ and subsequently, in the development of metastasis $[35,36,44,45]$. Based on the special characteristics of uveal melanoma, our further aim was to investigate the effect of AEZS-108 on the expression of the genes related to angiogenesis and migration in OCM3 cells by qRT-

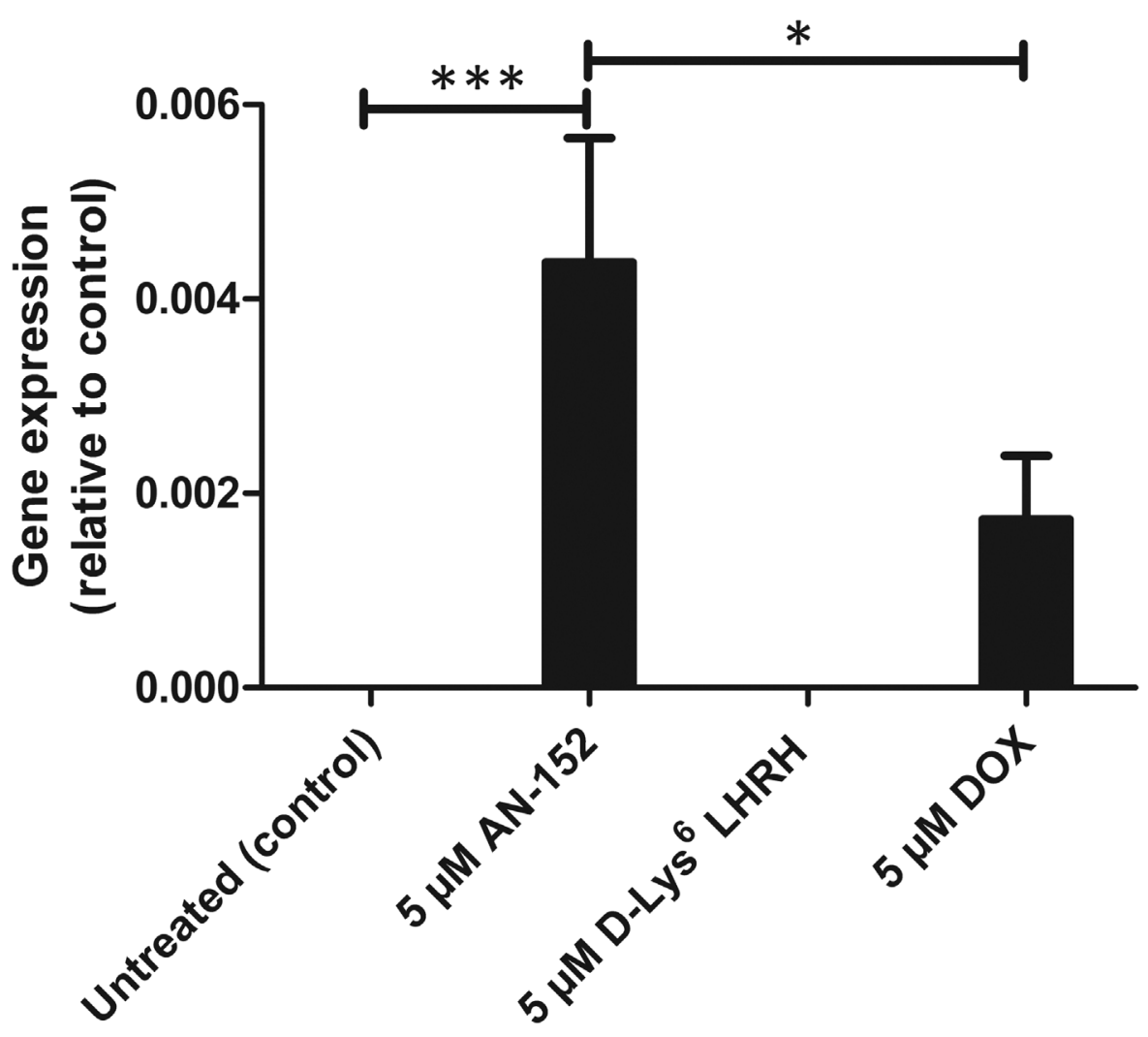

Figure 3: Treatment with AEZS-108 at equal doses with DOX was significantly more effective in the upregulation of MASPIN than free DOX. The expression of MASPIN tumor suppressor was measured by qRT-PCR from three independent experiments. For comparison, the corresponding mRNA expression levels of MASPIN are shown below the qPCR graphs for each treatments. Statistical analysis was performed by one-way ANOVA $\left({ }^{*}\right.$ : significant, $p<0.05$; $^{* * *}$ : extremely significant, $\left.p<0.005\right)$. 


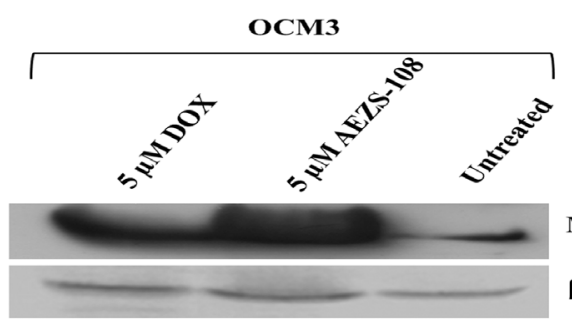

Maspin (42kDa)

$\beta$-actin (42kDa)
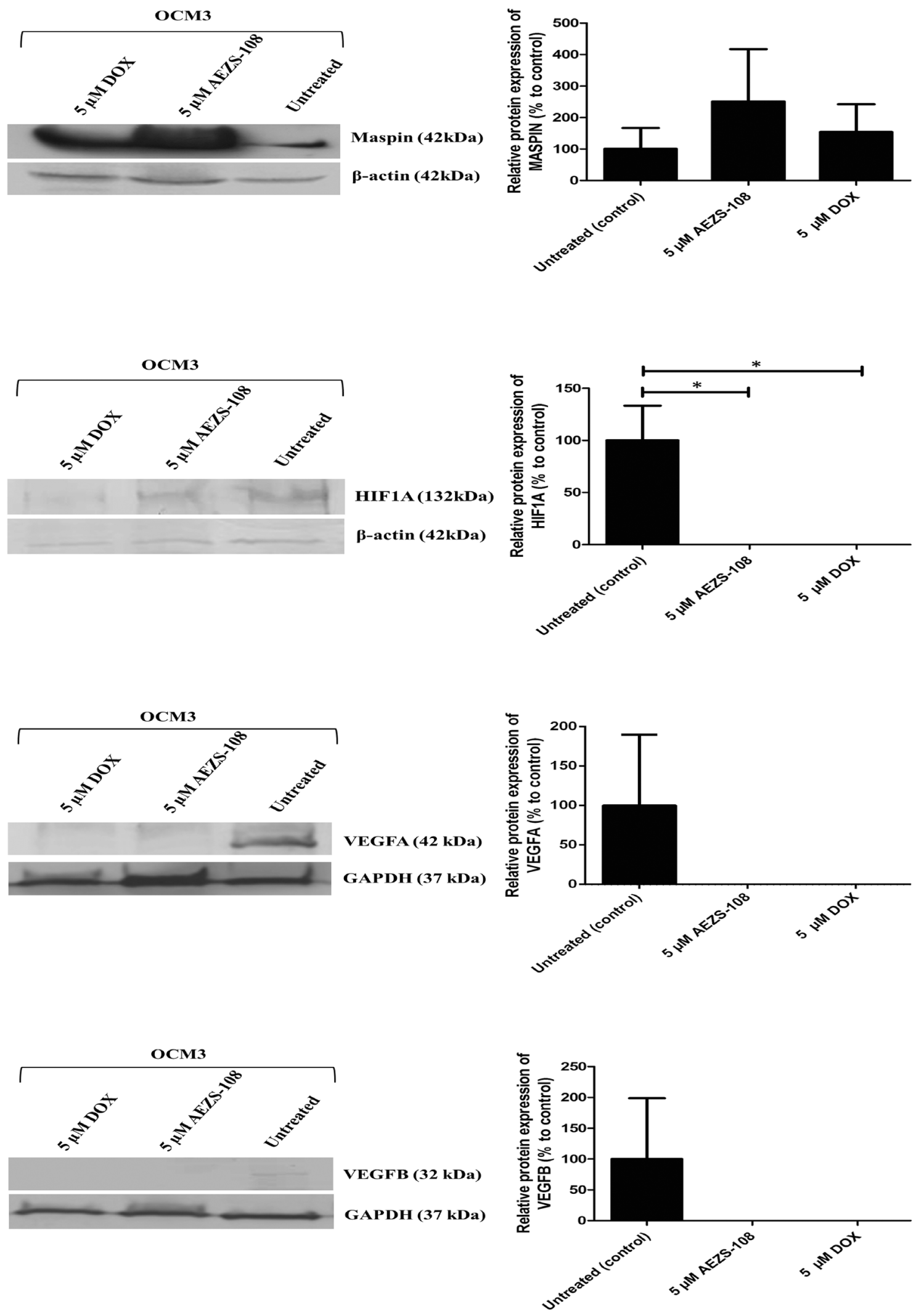

Figure 4: Western blot analysis of MASPIN, HIF1A, VEGFA and VEGFB protein expression after 24 hours of treatment with $5 \mu M$ AEZS-108 and $5 \mu M$ free DOX treatments from OCM3 cells. $40 \mu \mathrm{g}$ of protein from each sample was separated on 12\% SDS PAGE and transferred to PVDF or nitrocellulose membranes and probed with specific antibodies (described in Materials and metods). Data represents the densitometric analysis of the results to the target proteins normalized to $\beta$-actin or GAPDH. Statistical analysis was performed by one-way ANOVA ( ${ }^{*}$ : significant, $\left.p<0.05\right)$. 
PCR array. The tumor suppressor MASPIN (SERPINB5) and SERPINE1 genes showed the highest overexpression, while the most significantly downregulated genes were $H I F 1 A$ and its target genes, also involved in angiogenesis and metastasis of cancer cells. The observed changes in mRNA expression have been confirmed at protein level by Western blot analysis.

In terms of function these findings support a central role for MASPIN and HIF $1 A$ in ECM and in the regulation of angiogenesis in UM whereas the published data on role of these two genes for the survival of UM is relatively limited [46, 47].

Previous studies have demonstrated the role of MASPIN and SERPINE1 in the coordination of ECM proteolytic system and its important functions in cell migration, proliferation and survival [46]. MASPIN and SERPINE1 are natural inhibitors of $u P A / u P A R$ signaling, which is strengthened during inflammation, tissue remodeling and in many cancers, frequently indicating a poor prognosis [46] (Figure 5). We have detected that both MASPIN and SERPINE1, UPAR signaling inhibitors were simultaneously upregulated by treatment with AEZS-108. Controversially, HIF1A, the central regulator of angiogenesis was downregulated. HIF $1 A$ induces tumor hypoxia driving $u P A R$ expression through a hypoxia responsible element (HRE) in the $u P A R$ promoter. Furthermore, $u P A R$ is required for the induction of an epithelial-mesenchymal transition-like response in other cancer cell lines following exposure to hypoxia [46, 48]. Previously demonstrated data in accordance with our results might suggest that AEZS-108 induces a well regulated signaling pathway against ECM degradation, angiogenesis and migration of tumor cells via the regulation of MASPIN, HIF $1 A$ and their target genes [46].

In order to investigate the mechanism of the induction of MASPIN, OCM3 cells were treated with free DOX, D-Lys ${ }^{6}$ LHRH analog, or AEZS-108. AEZS-108 induced greater MASPIN expression compared to free DOX. Unconjugated D-Lys ${ }^{6}$ LHRH analog had no effect on the induction of MASPIN. Based on our results, we assume that the induction of MASPIN is independent of the LHRH ligand-receptor interaction, and is probably triggered only by the cytotoxic DOX unit. The upregulation of MASPIN expression might be explained by a probable decrease in transporter activity in the presence of AEZS-108 [49].

We have also evaluated the expression of MASPIN expression in healthy human uvea and in human UM tissue specimens. According to our results, MASPIN is undetectable in healthy uvea and in UM tissues. Diminished expression of MASPIN in the UM specimens is congruent with a previous study, in which the decreased $M A S P I N$ expression in UM tissue specimens indicated poor prognosis due to therapy resistance [50].

In summary, our data confirmed previous results showing LHRH receptor expression in OCM3 cells, an $\mathrm{UM}$ in vitro model. Furthermore, we report for the first time that AEZS-108 causes changes in the expression of genes which are involved in angiogenesis and ECM degradation and which might inhibit cell proliferation and induce apoptosis in OCM3 cells.

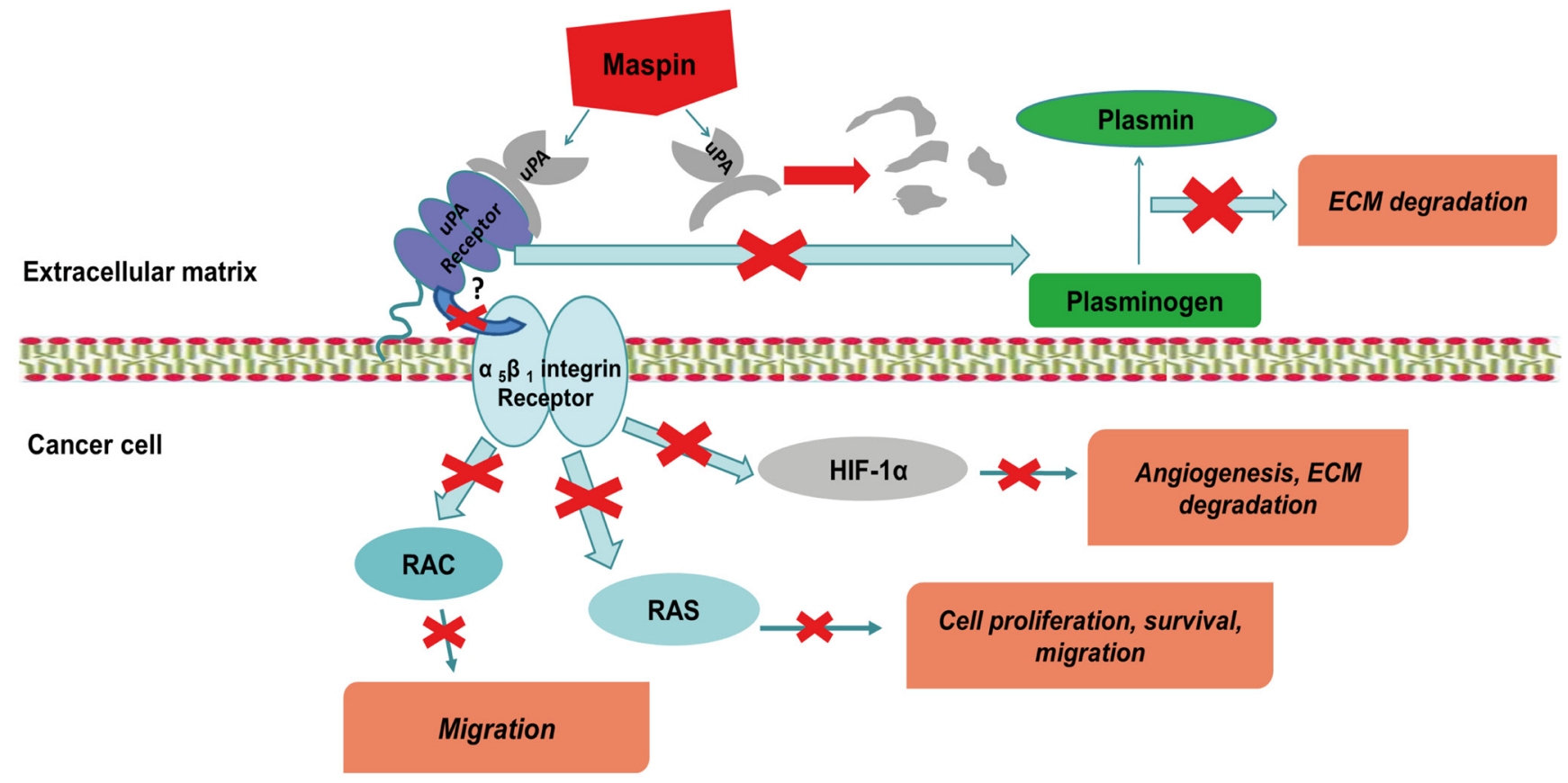

Figure 5: MASPIN can prevent the formation of UPA - UPA-receptor complex by a single step, and thus decrease the possibility of the abnormal degradation of the ECM, the development metastasis and angiogenesis. (UPA: urokinase type plasminogen activator, UPAR: UPA-receptor, HIF1A: hypoxia-inducible factor 1 alpha ECM: extracellular matrix, RAS: GTP-binding protein, RAC: subfamily of RHO-GTP-ases). 
These findings suggest that AEZS-108 plays a pivotal role in the regulation of angiogenesis and tumor suppression. Taken together, targeted cytotoxic LHRH analogs, such as AEZS-108, might serve as an effective treatment for patients with LHRH receptor positive uveal melanoma.

\section{MATERIALS AND METHODS}

\section{Ethics statement}

The local Institutional Ethics Committee of the University of Debrecen approved the collection and use of human pituitary, normal uvea and uveal melanoma specimens for the current study and informed consent was obtained from these patients (ID number: DERKEB/ IKEB 4172-2014). Uvea and uveal melanoma specimens were obtained at the time of initial surgical treatment at the Department of Ophthalmology, University of Debrecen, Hungary. Normal pitutaries were collected by autopsy at the Department of Pathology, University of Debrecen, Hungary.

\section{Cell line and culturing conditions}

The human metastatic uveal melanoma cell line, OCM3 (ocular choroideal melanoma 3, cultured from primary tumor) was kindly provided by the Department of Biophysics and Cell Biology, Faculty of Medicine, University of Debrecen. OCM3 cells were cultured in complete growth medium: RPMI 1640 medium supplemented with L-glutamine (PPA Labotatories, Austria), $10 \%$ fetal bovine serum (FBS) (PPA Labotatories, Austria) and $100 \mathrm{U} / \mathrm{ml}$ Penicillin, $100 \mathrm{mg} /$ $\mathrm{ml}$ Streptomycin (Pen/Strep, TEVA Pharmaceuticals Zrt., Hungary) in a humidified chamber (95\% air humidity, 5\% $\mathrm{CO}_{2}$ ) at $37^{\circ} \mathrm{C}$.

\section{Detection of LHRH receptor in $\mathrm{OCM} 3$ cells by immunocytochemistry}

Cells were seeded into a 96-well plate at the density of 25.000 cells/well in complete growth medium and were left to adhere overnight. On the following day, cells were rinsed with PBS $(\mathrm{pH} 7.4)$ and fixed in cold methanol for 10 minutes. Endogenous peroxidase activity was blocked with $3 \% \mathrm{H}_{2} \mathrm{O}_{2}$. Cells were permeabilized by adding $0.1 \%$ Triton X-100 in PBS. Non-specific binding sites were blocked with $1 \%$ FBS and $0.1 \%$ Triton X-100 containing PBS (60 min, room temperature). Cells were incubated with human LHRH receptor type I antibody (Santa Cruz Biotechnology, USA, FL-328; sc-13944) in 1:100 dilution in PBS overnight at $4^{\circ} \mathrm{C}$. Next day, cells were stained with horseradish peroxidase (HRP)conjugated secondary antibody (anti-rabbit IgG (Fab) of EnVision+ kit, (DM822) Dako, Denmark) according to the manufacturer's instructions. Human pituitary glands (anterior lobe) obtained from autopsy at the University of Debrecen were used as positive controls.

Negative controls (primary antibody was replaced by normal serum) were also included. DAB chromogenic staining of the receptors was detected by SPOT ${ }^{\mathrm{TM}}$ Imaging Software (Dioganostic Instruments Inc., USA) and Nikon Eclipse TS/100 microscope (Nikon Instruments, Melville, NY).

\section{Detection of LHRH receptor type I in OCM3 cells after RNA isolation by reverse transcription (RT)-PCR}

Total RNA was isolated from OCM3 cells using the AllPrep DNA/RNA/Protein Mini kit (Qiagen, Germany). $500 \mathrm{ng}$ of RNA from each sample was reverse transcribed into cDNA by QuantiTect Reverse Transcription kit (Qiagen, Germany). The following primer pair has been used to detect LHRH-R type I: 5'GAC CTT GTC TGG AAA GAT CC -3' (sense), 5'- CAG GCT GAT CAC CAC CAT CA -3' (antisense) (SigmaAldrich Corporation, USA). Primers were designed using Primer3web softwer. One $\mu$ of cDNA was amplified in a $25 \mu \mathrm{l}$ solution containing $1.5 \mathrm{mM} \mathrm{MgCl}_{2}, 1 \times$ PCR buffer (Fermentas, Germany), $0.3 \mathrm{mM}$ of each deoxynucleotide (Promega, Germany), 1 unit of TrueStart HotStart DNA polymerase (Fermentas, Germany) and $0.25 \mu \mathrm{M}$ of each primer. Samples were subjected to 40 cycles of $95^{\circ} \mathrm{C}$ for $45 \mathrm{~s}, 59^{\circ} \mathrm{C}$ for $30 \mathrm{~s}$, then $72^{\circ} \mathrm{C}$ for $1.5 \mathrm{~min}$ with a final extension of $10 \mathrm{~min}$ at $72^{\circ} \mathrm{C}$. Normal human pituitaries, collected at autopsy, served as positive control. Human uveal melanoma specimens, previously investigated by us [1] were also used to confirm the expression of LHRH receptors. No template control (NTC) was used to detect potential contaminations in the RT-PCR reactions. PCR cycles have been performed using the Bio-Rad C1000 TM Thermal Cycler (Bio-Rad Laboratories, USA) instrument. $10 \mu \mathrm{l}$ of each amplification reaction was then electrophoretically separated on $1.5 \%$ agarose gel, stained with GelRed (Biotinum, USA), and visualized under UV light.

\section{Cytotoxic and LHRH ligand analogs and doxorubicin}

The targeted cytotoxic analog, AEZS-108 (formerly known as AN-152/ INN: Zoptarelin Doxorubicin Acetate), corresponding to D-Lys ${ }^{6}$ LHRH (pyroGlu-His-Trp-SerTyr-D-Lys-Leu-Arg-Pro-Gly-NH2) linked to doxorubicin (DOX) was first sythesized by solid-phase method, as described by the laboratory of Andrew V. Schally [6, 7, 42]. The AEZS-108 and D-Lys ${ }^{6}$ LHRH used in our experiments was kindly provided by AEterna/ Zentaris (Frankfurt am Main, Germany). Doxorubicin-HCl (2 mg/ml) (DOX) was purchased from Teva Pharmaceutical Works Ltd. (Hungary). 
The compounds were dissolved in $\mathrm{NaCl}$ (Salsol-A, Teva Pharmaceutical Works Ltd., Hungary) containing $0.01 \mathrm{M}$ aqueous acetic acid at a stock concentration of $100 \mu \mathrm{M}$. Based on previous studies, compounds were used in $5 \mu \mathrm{M}$ concentration $[33,51]$.

\section{Determination of cell viability by MTS assay}

Cells were seeded into a 96-well plate at the density of 10.000 cells/well in complete growth medium and incubated for 24 hours. Afterwards, medium was completely replaced with $5 \mu \mathrm{M}$ cytotoxic compoundcontaining growth medium and cells were incubated for additional 24 hours. Subsequently, MTS assay was performed in order to quantify viable cells (CellTiter 96 AQueous One Solution Assay Assay (Promega, Madison, WI). The assay was done according to the manufacturer's protocol. All treatments were performed in hexaplicates ( $n$ $=6)$. Absorbance was measured at $490 \mathrm{~nm}$ in a FLUOstar Optima Counter (BMG Labtech GmbH, Germany). Values were expressed relative to the control.

\section{Treatment of OCM3 cells and RNA isolation}

OCM3 cells were seeded and cultured in T25 cell culture flasks for 24 hours, until forming a confluent monolayer. Next day the medium was discarded and replaced with either $5 \mu \mathrm{M}$ AEZS-108, DOX or D-Lys ${ }^{6}$ LH-RH analog containing complete growth medium. Cells were incubated for additional 24 hours. The treatment was performed in biological replicates $(n=3)$. Total RNA was isolated from treated and untreated (control) OCM3 cells by TRI Reagent (MRC, USA) according to the manufacturer's instructions. The homogenization of the tissue samples was performed with TissueRuptor ${ }^{\circledR}$ (Qiagen, Germany). RNA isolation process were carried out as previously described [52].

\section{RT- PCR and qRT-PCR with OCM3 samples}

Gene expression changes induced by treatment in the OCM3 cells were evaluated after RT-PCR. $500 \mathrm{ng}$ of total RNA from each sample was transcribed into cDNA IScript Reverse Transcriptase Kit (Bio-Rad Laboratories, USA) respectively, according to the manufacturer's instructions.

In order to investigate the expression of genes involved in angiogenesis and metastasis regulatory factors after treatment of OCM3 cells with cytotoxic AEZS-108, Human Angiogenesis 96 StellArray ${ }^{\mathrm{TM}}$ (Lonza Ltd., USA) plates and SYBR Green Supermix (Bio-Rad Laboratories, USA) were used according to the manufacturer's protocol. qRT-PCR arrays were performed with untreated and AEZS-108- treated OCM3 samples in biological replicates $(n=3)$. Samples were subjected to an initial anellation step $\left(50^{\circ} \mathrm{C}\right.$ for $\left.2 \mathrm{~min}\right)$ followed by the activation of enzyme $\left(95^{\circ} \mathrm{C}\right.$ for $\left.3 \mathrm{~min}\right)$, then 40 cycles of amplification $\left(95^{\circ} \mathrm{C}\right.$ for $15 \mathrm{sec}, 60^{\circ} \mathrm{C}$ for $1 \mathrm{~min}$ ) and 81 cycles of melting curves $\left(55^{\circ} \mathrm{C}-98^{\circ} \mathrm{C}\right.$ for $\left.0.5 \mathrm{~min} /{ }^{\circ} \mathrm{C}\right)$. Results were normalized by the Global Pattern Recognition algorithm (Bar Harbor Bio Technology Inc.'s, USA) and quantified by $\Delta \Delta \mathrm{Ct}$ method.

Based on the results of the array, particularly, the expression of MASPIN tumor suppressor gene has been further investigated after treatment with AEZS-108, DOX or D-Lys ${ }^{6}$ LHRH using SYBR Green Supermix (Bio-Rad Laboratories, USA) in a $20 \mu$ l total volume according to the manufacturer's instructions. The following primer pair has been used for MASPIN: 5' -TCAACAAGACAGACACCAAACC - 3' (sense), 5'GGAACTCATCCTCCACATCCT - 3' (Sigma-Aldrich Corporation, USA). Primers were designed using Primer3web softwer. PCR cycles were run as described in the qRT-PCR array experiment. Gene expression has been quantified by the $40-\mathrm{C}_{\mathrm{T}}$ method. Results were normalized to the expression of $\beta$-actin and HPRT housekeeping genes. cDNA sample from HaCaT cells was used as a positive control and no template control (NTC) to detect potential contaminations in the reactions. PCR cycles have been performed using the Bio-Rad C1000 ${ }^{\mathrm{TM}}$ Thermal Cycler and the Bio-Rad MyiQ2 ${ }^{\mathrm{TM}}$ Real Time qPCR (BioRad Laboratories, USA) instruments.

\section{RNA isolation and reverse transciption of human tissue samples}

Human uveal melanoma specimens were obtained from 18 patients, 30-84 years old at the time of enucleation. Three normal uvea samples were collected from healthy patients after severe eye accident. After surgical removal, selected portions of the tissues were snap-frozen and stored at $-70^{\circ} \mathrm{C}$. In all cases, histopathological examination confirmed the diagnosis. Total RNA was isolated using the AllPrep DNA/RNA/ Protein Mini kit (Qiagen, Germany). 500 ng RNA from each sample was reverse transcribed into cDNA by QuantiTect Reverse Transcription kit (Qiagen, Germany) according to the manufacturer's instructions.

\section{Detection of MASPIN with RT-PCR in human uveal melanoma and healthy uvea tissue specimens}

Based on our qRT-PCR results, the gene expression of MASPIN (SERPINB5) has been further examined in human uveal melanoma and healthy human uvea specimens. The following primer pairs were used: 5' - GGCAATGTCCTCTTCTCTCC - 3' (sense), 5'GCCGCTTGATTAGTTTCAGT - 3' (antisense) (SigmaAldrich Corporation, USA). Primers were designed using Primer3web softwer. $1 \mu \mathrm{l}$ of the cDNA was amplified in $25 \mu \mathrm{l}$ solution containing $1.5 \mathrm{mM} \mathrm{MgCl}, 1 \times \mathrm{mPCR}_{2}$ buffer (Fermentas, Germany), $0.3 \mathrm{mM}$ of each deoxynucleotide 
(Promega, Germany), 1 unit of DNA polymerase (Fermentas, Germany) and $0.1 \mu \mathrm{M}$ of each primer. Samples were subjected to an initial denaturation $\left(95^{\circ} \mathrm{C}\right.$ for $\left.3 \mathrm{~min}\right)$ followed by 35 cycles of amplification $\left(95^{\circ} \mathrm{C}\right.$ for $45 \mathrm{sec}$, $60^{\circ} \mathrm{C}$ for $30 \mathrm{sec}, 72^{\circ} \mathrm{C}$ for $1.5 \mathrm{~min}$ ) and a final elongation step $\left(72^{\circ} \mathrm{C}\right.$ for $\left.10 \mathrm{~min}\right)$. As positive control we used $\mathrm{HaCaT}$ cDNA samples. No template control (NTC) has been used to detect potential contaminations in the reactions. $10 \mu \mathrm{l}$ of each amplification reaction was then electrophoretically separated on $1.5 \%$ agarose gel, stained with GelRed (Biotinum, USA), and visualized under UV light.

\section{Protein analysis}

Total protein was isolated from untreated, AEZS108- or DOX-treated cells using TRI Reagent (MRC, USA) and purified with isopropyl alcohol (Sigma-Aldrich Corporation, USA), $300 \mathrm{mM}$ guanidine-hydrochloride (Amresco, VWR) and 96\% ethanol (Scharlab, Hungary) according to the manufacturer's instructions. The final pellet was resuspended in $1 \%$ SDS buffer containing protease inhibitors; $0.4 \%(\mathrm{v} / \mathrm{v})$ aprotinin (Sigma-Aldrich Corporation, USA), $2 \mu \mathrm{g} / \mathrm{ml}$ pepstatin A (Sigma-Aldrich Corporation, USA) and leupeptin (Sigma-Aldrich Corporation, USA) and stored until use at $-80^{\circ} \mathrm{C}$. Protein concentration was determined by Bradford method [53, 54]. $40 \mu \mathrm{g}$ protein has been separated on $12 \%$ SDS PAGE and transferred to PVDF or nitrocellulose membrane. $5 \%$ nonfat dry milk or BSA has been used as blocking agent in Tris buffered saline containing 0.1\% Tween-20. Primary antibodies (Santa Cruz Biotechnology, USA and Cell Signaling Technology, USA) were applied at the following concentrations: MASPIN (C-8; sc271694) in 1:100; HIF1A (HIF1A (H-206; sc-10790) in 1:200; VEGFA (VEGF (A-20; sc-152) in 1:100; VEGFB (VEGFB (MM0008-7B43; sc-101581) in $1: 200$ and GAPDH (D16H11 $\left.\mathrm{XP}^{(\mathrm{R})}\right)$ in 1:1000. Primary antibodies were stained with alkaline-phosphatase or horseradish-peroxidase conjugated secondary antibodies (Santa Cruz Biotechnology, USA) and detected using AP Conjugate Substrate Kit (Bio-Rad Laboratories, USA) or WesternBright ${ }^{\mathrm{TM}}$ ECL Substrate Kit (Advanstra Corporation, USA). Results were acquired and analyzed with the Molecular Image Chemidoc XRS+ System using Image Lab Software 5.2 (Bio-Rad Laboratories, USA).

\section{Statistical analysis}

Data were analyzed by Students's $t$-test or one-way ANOVA followed by Tukey post hoc test to determine the differences between the selected groups using the program Prism 5 software (GraphPad Software, Inc., USA) and with IBM SPSS Statistics (IBM Corp. Released 2014. IBM SPSS Statistics for Windows, Version 23.0. Armonk, NY: IBM Corp.). Data are presented as a mean value \pm standard error of the mean (SEM). A $p$ value $* 0.05$ was considered to be statistically significant ( $p$ value ${ }^{* *}<0.01$ : highly significant, $p$ value ${ }^{* * *}<0.005$ : extremely significant).

\section{Abbreviations}

UM: uveal melanoma; OCM3: ocular chorioideal melanoma 3, cultured from primary tumor; LHRH: Luteinizing Hormone-Releasing Hormone; LHRH-R: Luteinizing Hormone-Releasing Hormone receptor; DOX: doxorubicin; D-Lys ${ }^{6}$ LHRH analog: (pyroGluHis-Trp-Ser-Tyr-D-Lys-Leu-Arg-Pro-Gly-NH2) LHRH analog; AEZS-108 (formerly known as AN-152/INN: Zoptarelin Doxorubicin Acetate): D-Lys ${ }^{6}$ LHRH analog linked to doxorubicin; HIF1A: Hypoxia-inducible factor 1 alpha; MASPIN (SERPINB5): Serpin peptidase inhibitor clade B, member 5; SERPINE1 (PAI-1): Serpin family E, member 1; ETS1: ETS Proto-Oncogene 1, Transcription Factor; CEACAM: Carcinoembryonic Antigen Related Cell Adhesion Molecule; SURVIVIN: BIRC5, Baculoviral IAP Repeat Containing 5; VEGFA: Vascular Endothelial Growth Factor A; VEGFB: Vascular Endothelial Growth Factor B; ANGPT1: Angiopoietin 1; MAPK7: MitogenActivated Protein Kinase 7; CXCR4: C-X-C Motif Chemokine Receptor 4; ECM: extracellular matrix; qRT- PCR: quantitative reverse transcription- polymerase chain reaction; FBS: fetal bovine serum; PBS: phosphate buffered salin; HRP: horseradish peroxidase.

\section{Author contributions}

Klara Fodor performed all the major experimental work required in this study and take part in the preparation of the manuscript. Andrea Treszl designed in part the concept of the study and the primers for the PCR assays. Gabor Olah and Eva Sipos worked in the RNA and protein isolation processes and in data analysis. Zita Steiber collected the normal uvea and uveal menanoma tissue specimens and analysed data. Nikoletta Dobos participated in the statistical evaluation and in the interpretation of the results as well as in the composition and revision of the manuscript. Andrew Victor Schally, Lorant Szekvölgyi and Gabor Halmos helped with the concept and the preparation of the manuscript and made the critical revision of the work.

\section{ACKNOWLEDGMENTS}

This work is in memory of the late Andrea Treszl, Ph.D., who died of metastatic breast cancer. Her intellectual and personal contributions gave us great motivation.

\section{CONFLICTS OF INTEREST}

Dr. A.V. Schally is listed as a co-inventor on the patents of Tulane University on AEZS-108. All authors declare no conflicts of interest. 


\section{FUNDING}

This work was supported by Hungarian Scientific Research Fund (OTKA) K 81596 (G.H.), TAMOP 4.2.2.A- 11/1/KONV-2012-0025 project (G.H.), GINOP-2.3.2-15-2016-00043 (G.H.), GINOP-2.3.2-15-2016-00024 (L.Sz.), LENDÜLET Program, LP2015-9/2015 (L.Sz.) and the Gedeon Richter's Talentum Foundation (K.F.) The research was also financed by the framework of the Biotechnology Thematic Programme of the University of Debrecen (20428-3/2018/FEKUTSRAT) (G.H.), and it was cofinanced by the European Union and the State of Hungary, by the European Social Fund in the framework of TÁMOP-4.2.4.A/2-11-1-2012-0001 'National Excellence' Program (K.F.).

\section{REFERENCES}

1. Treszl A, Steiber Z, Schally AV, Block NL, Dezso B, Olah G, Rozsa B, Fodor K, Buglyo A, Gardi J, Berta A, Halmos G. Substantial expression of luteinizing hormonereleasing hormone (LHRH) receptor type I in human uveal melanoma. Oncotarget. 2013; 4:1721-1728. https://doi. org/10.18632/oncotarget.1379. [PubMed]

2. Baggetto LG, Gambrelle J, Dayan G, Labialle S, Barakat S, Michaud M, Grange JD, Gayet L. Major cytogenetic aberrations and typical multidrug resistance phenotype of uveal melanoma: current views and new therapeutic prospects. Cancer Treat Rev. 2005; 31:361-379. https://doi. org/10.1016/j.ctrv.2005.05.001. [PubMed]

3. Damato B. Does ocular treatment of uveal melanoma influence survival? Br J Cancer. 2010; 103:285-290. https:// doi.org/10.1038/sj.bjc.6605765. [PubMed]

4. Eskelin S, Pyrhonen S, Hahka-Kemppinen M, Tuomaala $\mathrm{S}$, Kivela T. A prognostic model and staging for metastatic uveal melanoma. Cancer. 2003; 97:465-475. https://doi. org/10.1002/cncr.11113. [PubMed]

5. Augsburger JJ, Correa ZM, Shaikh AH. Effectiveness of treatments for metastatic uveal melanoma. Am J Ophthalmol. 2009; 148:119-127. https://doi.org/10.1016/j. ajo.2009.01.023. [PubMed]

6. Schally AV, Nagy A. Cancer chemotherapy based on targeting of cytotoxic peptide conjugates to their receptors on tumors. Eur J Endocrinol. 1999; 141:1-14. https://doi. org/10.1530/eje.0.1410001. [PubMed]

7. Schally AV, Nagy A. Chemotherapy targeted to cancers through tumoral hormone receptors. Trends Endocrinol Metab. 2004; 15:300-310. https://doi.org/10.1016/j. tem.2004.07.002. [PubMed]

8. Schally AV, Engel JB, Emons G, Block NL, Pinski J. Use of analogs of peptide hormones conjugated to cytotoxic radicals for chemotherapy targeted to receptors on tumors. Curr Drug Deliv. 2011; 8:11-25. https://doi. org/10.2174/156720111793663598. [PubMed]
9. Engel JB, Tinneberg HR, Rick FG, Berkes E, Schally AV. Targeting of Peptide Cytotoxins to LHRH Receptors For Treatment of Cancer. Curr Drug Targets. 2016; 17:488-494. https://doi.org/10.2174/138945011705160303154717. [PubMed]

10. Rick FG, Saadat SH, Szalontay L, Block NL, Kazzazi A, Djavan B, Schally AV. Hormonal manipulation of benign prostatic hyperplasia. Curr Opin Urol. 2013; 23:17-24. https://doi.org/10.1097/MOU.0b013e32835abd18. [PubMed]

11. Emons G, Gorchev G, Sehouli J, Wimberger P, Stahle A, Hanker L, Hilpert F, Sindermann H, Grundker C, Harter P. Efficacy and safety of AEZS-108 (INN: zoptarelin doxorubicin acetate) an LHRH agonist linked to doxorubicin in women with platinum refractory or resistant ovarian cancer expressing LHRH receptors: a multicenter phase II trial of the ago-study group (AGO GYN 5). Gynecol Oncol. 2014; 133:427-432. https://doi. org/10.1016/i.ygyno.2014.03.576. [PubMed]

12. Emons G, Kaufmann M, Gorchev G, Tsekova V, Grundker C, Gunthert AR, Hanker LC, Velikova M, Sindermann H, Engel J, Schally AV. Dose escalation and pharmacokinetic study of AEZS-108 (AN-152), an LHRH agonist linked to doxorubicin, in women with LHRH receptor-positive tumors. Gynecol Oncol. 2010; 119:457-461. https://doi. org/10.1016/j.ygyno.2010.08.003. [PubMed]

13. Liu SV, Tsao-Wei DD, Xiong S, Groshen S, Dorff TB, Quinn DI, Tai YC, Engel J, Hawes D, Schally AV, Pinski JK. Phase I, dose-escalation study of the targeted cytotoxic LHRH analog AEZS-108 in patients with castration- and taxaneresistant prostate cancer. Clin Cancer Res. 2014; 20:62776283. https://doi.org/10.1158/1078-0432.CCR-14-0489. [PubMed]

14. Tolkach Y, Joniau S, Van Poppel H. Luteinizing hormonereleasing hormone (LHRH) receptor agonists vs antagonists: a matter of the receptors? BJU Int. 2013; 111:1021-1030. https://doi.org/10.1111/j.1464-410X.2013.11796.x. [PubMed]

15. Harrison GS, Wierman ME, Nett TM, Glode LM. Gonadotropin-releasing hormone and its receptor in normal and malignant cells. Endocr Relat Cancer. 2004; 11:725748. https://doi.org/10.1677/erc.1.00777. [PubMed]

16. Tieva A, Stattin P, Wikstrom P, Bergh A, Damber JE. Gonadotropin-releasing hormone receptor expression in the human prostate. Prostate. 2001; 47:276-284. https://doi. org/10.1002/pros.1072. [PubMed]

17. Tieva A, Wilkstrom P, Olofsson JI, Bergh A, Damber JE. Expression of gonadotropin-releasing hormone receptor mRNA in the rat ventral prostate and dunning R3327 PAP adenocarcinoma before and after castration. Prostate. 1999; 39:101-107. https://doi.org/10.1002/(SICI)10970045(19990501)39:2<101::AID-PROS4>3.0.CO;2-J. [PubMed]

18. Jaszberenyi M, Schally AV, Block NL, Nadji M, Vidaurre I, Szalontay L, Rick FG. Inhibition of U-87 MG glioblastoma by AN-152 (AEZS-108), a targeted cytotoxic analog 
of luteinizing hormone-releasing hormone. Oncotarget. 2013; 4:422-432. https://doi.org/10.18632/oncotarget.917. [PubMed]

19. Rick FG, Schally AV, Block NL, Abi-Chaker A, Krishan A, Szalontay L. Mechanisms of synergism between antagonists of growth hormone-releasing hormone and antagonists of luteinizing hormone-releasing hormone in shrinking experimental benign prostatic hyperplasia. Prostate. 2013; 73:873-883. https://doi.org/10.1002/pros.22633. [PubMed]

20. Rick FG, Schally AV, Block NL, Halmos G, Perez R, Fernandez JB, Vidaurre I, Szalontay L. LHRH antagonist Cetrorelix reduces prostate size and gene expression of proinflammatory cytokines and growth factors in a rat model of benign prostatic hyperplasia. Prostate. 2011; 71:736-747. https://doi.org/10.1002/pros.21289. [PubMed]

21. Rick FG, Szalontay L, Schally AV, Block NL, Nadji M, Szepeshazi K, Vidaurre I, Zarandi M, Kovacs M, Rekasi Z. Combining growth hormone-releasing hormone antagonist with luteinizing hormone-releasing hormone antagonist greatly augments benign prostatic hyperplasia shrinkage. J Urol. 2012; 187:1498-1504. https://doi.org/10.1016/j. juro.2011.11.081. [PubMed]

22. Volker P, Grundker C, Schmidt O, Schulz KD, Emons G. Expression of receptors for luteinizing hormone-releasing hormone in human ovarian and endometrial cancers: frequency, autoregulation, and correlation with direct antiproliferative activity of luteinizing hormone-releasing hormone analogues. Am J Obstet Gynecol. 2002; 186:171179. https://doi.org/10.1067/mob.2002.119633. [PubMed]

23. Imai A, Ohno T, Iida K, Fuseya T, Furui T, Tamaya T. Gonadotropin-releasing hormone receptor in gynecologic tumors. Frequent expression in adenocarcinoma histologic types. Cancer. 1994; 74:2555-2561. https:// doi.org/10.1002/1097-0142(19941101)74:9<2555::AIDCNCR2820740925>3.0.CO;2-X. [ [PubMed]

24. Friess H, Buchler M, Kiesel L, Kruger M, Beger HG. LH$\mathrm{RH}$ receptors in the human pancreas. Basis for antihormonal treatment in ductal carcinoma of the pancreas. Int $\mathrm{J}$ Pancreatol. 1991; 10:151-159. [ubMed]

25. Bahk JY, Kim MO, Park MS, Lee HY, Lee JH, Chung $\mathrm{BC}$, Min SK. Gonadotropin-releasing hormone $(\mathrm{GnRH})$ and $\mathrm{GnRH}$ receptor in bladder cancer epithelia and $\mathrm{GnRH}$ effect on bladder cancer cell proliferation. Urol Int. 2008; 80:431-438. https://doi.org/10.1159/000132703. [PubMed]

26. Baumann KH, Kiesel L, Kaufmann M, Bastert G, Runnebaum B. Characterization of binding sites for a GnRH-agonist (buserelin) in human breast cancer biopsies and their distribution in relation to tumor parameters. Breast Cancer Res Treat. 1993; 25:37-46. https://doi.org/10.1007/ BF00662399. [PubMed]

27. Halmos G, Arencibia JM, Schally AV, Davis R, Bostwick DG. High incidence of receptors for luteinizing hormone-releasing hormone (LHRH) and LHRH receptor gene expression in human prostate cancers. J Urol. 2000; 163:623-629. https:// doi.org/10.1016/S0022-5347(05)67947-5. [PubMed]
28. Buchholz S, Seitz S, Schally AV, Engel JB, Rick FG, Szalontay L, Hohla F, Krishan A, Papadia A, Gaiser T, Brockhoff G, Ortmann O, Diedrich K, et al. Triplenegative breast cancers express receptors for luteinizing hormone-releasing hormone (LHRH) and respond to LHRH antagonist cetrorelix with growth inhibition. Int J Oncol. 2009; 35:789-796. https://doi.org/10.3892/ijo_00000391. [PubMed]

29. Hohla F, Winder T, Greil R, Rick FG, Block NL, Schally AV. Targeted therapy in advanced metastatic colorectal cancer: current concepts and perspectives. World J Gastroenterol. 2014; 20:6102-6112. https://doi.org/10.3748/wjg.v20.i20.6102. [PubMed]

30. Szepeshazi K, Schally AV, Keller G, Block NL, Benten D, Halmos G, Szalontay L, Vidaurre I, Jaszberenyi M, Rick FG. Receptor-targeted therapy of human experimental urinary bladder cancers with cytotoxic LH-RH analog AN152 [AEZS- 108]. Oncotarget. 2012; 3:686-699. https://doi. org/10.18632/oncotarget.546. [PubMed]

31. Bajo AM, Schally AV, Halmos G, Nagy A. Targeted doxorubicin-containing luteinizing hormone-releasing hormone analogue $\mathrm{AN}-152$ inhibits the growth of doxorubicin-resistant MX-1 human breast cancers. Clin Cancer Res. 2003; 9:3742-3748. [PubMed]

32. Engel J, Emons G, Pinski J, Schally AV. AEZS-108: a targeted cytotoxic analog of LHRH for the treatment of cancers positive for LHRH receptors. Expert Opin Investig Drugs. 2012; 21:891-899. https://doi.org/10.1517/1354378 4.2012.685128. [PubMed]

33. Olah G, Dobos N, Vamosi G, Szabo Z, Sipos E, Fodor K, Harda K, Schally AV, Halmos G. Experimental therapy of doxorubicin resistant human uveal melanoma with targeted cytotoxic luteinizing hormone-releasing hormone analog (AN-152). Eur J Pharm Sci. 2018; 123:371-376. https:// doi.org/10.1016/j.ejps.2018.08.002. [PubMed]

34. Sipos E, Dobos N, Rozsa D, Fodor K, Olah G, Szabo Z, Szekvolgyi L, Schally AV, Halmos G. Characterization of luteinizing hormone-releasing hormone receptor type I (LHRH-I) as a potential molecular target in OCM-1 and OCM3 human uveal melanoma cell lines. OncoTargets Ther. 2018; 11:933-941. https://doi.org/10.2147/OTT.S148174. [PubMed]

35. Brouwer NJ, Gezgin G, Wierenga AP, Bronkhorst IH, Marinkovic M, Luyten GP, Versluis M, Kroes WG, van der Velden PA, Verdijk RM, Jager MJ. Tumour Angiogenesis in Uveal Melanoma Is Related to Genetic Evolution. Cancers (Basel). 2019; 11:E979. https://doi.org/10.3390/ cancers 11070979. [PubMed]

36. Castet F, Garcia-Mulero S, Sanz-Pamplona R, Cuellar A, Casanovas O, Caminal JM, Piulats JM. Uveal Melanoma, Angiogenesis and Immunotherapy, Is There Any Hope? Cancers (Basel). 2019; 11:834. https://doi.org/10.3390/ cancers 11060834. [PubMed]

37. Luke JJ, Triozzi PL, McKenna KC, Van Meir EG, Gershenwald JE, Bastian BC, Gutkind JS, Bowcock AM, 
Streicher HZ, Patel PM, Sato T, Sossman JA, Sznol M, et al. Biology of advanced uveal melanoma and next steps for clinical therapeutics. Pigment Cell Melanoma Res. 2015; 28:135-147. https://doi.org/10.1111/pcmr.12304. [PubMed]

38. Mariani P, Servois V, Piperno-Neumann S. Therapeutic options in metastatic uveal melanoma. Dev Ophthalmol. 2012; 49:166-181. https://doi.org/10.1159/000328333. [PubMed]

39. Pereira PR, Odashiro AN, Lim LA, Miyamoto C, Blanco PL, Odashiro M, Maloney S, De Souza DF, Burnier MN Jr. Current and emerging treatment options for uveal melanoma. Clin Ophthalmol. 2013; 7:1669-1682. https:// doi.org/10.2147/OPTH.S28863. [PubMed]

40. Croce M, Ferrini S, Pfeffer U, Gangemi R. Targeted Therapy of Uveal Melanoma: Recent Failures and New Perspectives. Cancers (Basel). 2019; 11:846. https://doi. org/10.3390/cancers11060846. [PubMed]

41. Gaiser T, Ruschoff J, Schally AV, Keller G, Engel JB. [Receptors for luteinizing hormone releasing hormone expressed on melanoma, renal cell carcinoma and non Hodgkin lymphoma can be used for targeted chemotherapy with cytotoxic luteinizing hormone releasing hormone analogues]. [Article in German]. Verh Dtsch Ges Pathol. 2006; 90:186-192. [PubMed]

42. Nagy A, Schally AV, Armatis P, Szepeshazi K, Halmos G, Kovacs M, Zarandi M, Groot K, Miyazaki M, Jungwirth A, Horvath J. Cytotoxic analogs of luteinizing hormone-releasing hormone containing doxorubicin or 2-pyrrolinodoxorubicin, a derivative 500-1000 times more potent. Proc Natl Acad Sci U S A. 1996; 93:7269-7273. https://doi.org/10.1073/pnas.93.14.7269. [PubMed]

43. Seitz S, Buchholz S, Schally AV, Weber F, KlinkhammerSchalke M, Inwald EC, Perez R, Rick FG, Szalontay L, Hohla F, Segerer S, Kwok CW, Ortmann O, et al. Triple negative breast cancers express receptors for LHRH and are potential therapeutic targets for cytotoxic LHRH-analogs, AEZS 108 and AEZS 125. BMC Cancer. 2014; 14:847. https://doi.org/10.1186/1471-2407-14-847. [PubMed]

44. Triozzi PL, Eng C, Singh AD. Targeted therapy for uveal melanoma. Cancer Treat Rev. 2008; 34:247-258. https:// doi.org/10.1016/j.ctrv.2007.12.002. [PubMed]

45. van den Bosch T, Kilic E, Paridaens D, de Klein A. Genetics of uveal melanoma and cutaneous melanoma: two of a kind? Dermatol Res Pract. 2010; 2010:360136. https://doi. org/10.1155/2010/360136. [PubMed]
46. Smith HW, Marshall CJ. Regulation of cell signalling by uPAR. Nat Rev Mol Cell Biol. 2010; 11:23-36. https://doi. org/10.1038/nrm2821. [PubMed]

47. Hu K, Babapoor-Farrokhran S, Rodrigues M, Deshpande M, Puchner B, Kashiwabuchi F, Hassan SJ, Asnaghi L, Handa JT, Merbs S, Eberhart CG, Semenza GL, Montaner S, et al. Hypoxia-inducible factor 1 upregulation of both VEGF and ANGPTL4 is required to promote the angiogenic phenotype in uveal melanoma. Oncotarget. 2016; 7:7816-7828. https:// doi.org/10.18632/oncotarget.6868. [PubMed]

48. Krishnamachary B, Berg-Dixon S, Kelly B, Agani F, Feldser D, Ferreira G, Iyer N, LaRusch J, Pak B, Taghavi P, Semenza GL. Regulation of colon carcinoma cell invasion by hypoxia-inducible factor 1 . Cancer Res. 2003; 63:1138-1143. [PubMed]

49. Kostryukova LV, Sanzhakov MA, Ignatov DV, Prozorovskyi VN, Druzhilovskaya OS, Kasatkina ES, Medvedeva NV, Ipatova OM. The increase in receptor-mediated endocytosis of drugs in the composition of nanoparticles with the address fragment. Biomed Khim. 2016; 62:306-310. https:// doi.org/10.18097/PBMC20166203306. [PubMed]

50. Nam E, Park C. Maspin suppresses survival of lung cancer cells through modulation of Akt pathway. Cancer Res Treat. 2010; 42:42-47. https://doi.org/10.4143/crt.2010.42.1.42. [PubMed]

51. Popovics P, Schally AV, Szalontay L, Block NL, Rick FG. Targeted cytotoxic analog of luteinizing hormone-releasing hormone (LHRH), AEZS-108 (AN-152), inhibits the growth of DU-145 human castration-resistant prostate cancer in vivo and in vitro through elevating $\mathrm{p} 21$ and ROS levels. Oncotarget. 2014; 5:4567-4578. https://doi.org/10.18632/ oncotarget.2146. [PubMed]

52. Likhite N, Warawdekar UM. A unique method for isolation and solubilization of proteins after extraction of RNA from tumor tissue using trizol. J Biomol Tech. 2011; 22:37-44. [PubMed]

53. Noble JE, Bailey MJ. Quantitation of protein. Methods Enzymol. 2009; 463:73-95. https://doi.org/10.1016/S00766879(09)63008-1. [PubMed]

54. Bradford MM. A rapid and sensitive method for the quantitation of microgram quantities of protein utilizing the principle of protein-dye binding. Anal Biochem. 1976; 72:248-254. https://doi.org/10.1016/0003-2697(76)90527-3. [PubMed] 